\title{
Microbiology and Biotechnology
}

http:/www.journals.zu.edu.eg/journalDisplay.aspx?Journalld=1\&queryType=Master

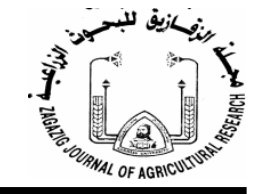

EFFECT OF INOCULATION WITH ARBUSCULAR MYCORRHIZAL FUNGI AND LABELED NITROGEN FERTILIZER ON ROOT COLONIZATION AND SPORE DENSITY OF SOME MEDICINAL PLANTS

\author{
Dina I.M. Abd El-Kader ${ }^{1 *}$, S.H. Salem ${ }^{2}$, Fatma I. El-Zamik ${ }^{2}$, Howaida M.L. Abd El-Basit ${ }^{2}$, \\ M.A. Rizk ${ }^{1}$ and O.A. Abd El-Aziz ${ }^{1}$ \\ 1. Soil and Water Res. Dept., Nuc. Res. Cen., Atomic Energy Authority, Inshas, Egypt \\ 2. Agric. Microbiol. Dept., Fac. Agric., Zagazig Univ., Egypt
}

Received: 11/06/2017 ; Accepted: 18/07/2017

\begin{abstract}
The present study was carried out to study the effect of inoculation with arbuscular mycorrhizal fungi (AMF) and some beneficial microbes under labeled nitrogen $\left({ }^{15} \mathrm{~N}\right)$ fertilization on AMF root colonization and spore density of some medicinal plants. The occurrences of AMF diversity have been studied in rhizosphere soils of 22 medicinal plants in Sekem Company Farm, and the percentage of mycorrhizal colonization on each plant and the number of spores per $100 \mathrm{~g}$ rhizosphere soil was calculated. AMF was observed in almost all plants. There were great variations in AMF colonization based on host plant. The highest root infection was observed in black cumin plant, being $77 \%$ and the lowest was in parsley plant, being $18.17 \%$. The highest spore population $(368 / 100 \mathrm{~g}$ rhizosphere soil) was recorded in anise plant and the lowest was observed in lemon grass plant (103/100g rhizosphere soil). The effects of AMF and microbial inoculation under labeled nitrogen fertilizer on root colonization of black cumin and anise plants after 30,60 and 120 days of cultivation and the rhizosphere spore density at the end of the experiment have been studied. The maximum AMF root colonization in black cumin plant was $83.67 \%$ after 120 days in the composite AMF, Azotobacter chroococcum and Bacillus megatherium in the presence of half nitrogen $\left({ }^{15} \mathrm{~N}\right)$ fertilizer dose, compared with the maximum AMF root colonization in anise plant that reached $76.67 \%$ after 120 days in the same treatment and the same nitrogen dose and this may be due to the difference between root exudates of two plants. The highest spore density in black cumin plant was $377 / 100 \mathrm{~g}$ soil with the composite treatment in the presence of half nitrogen $\left({ }^{15} \mathrm{~N}\right)$ fertilizer dose, while in anise plant it was 385/100g soil in the dual inoculation of AMF and Bacillus megatherium using half nitrogen dose.
\end{abstract}

Key words: Arbuscular mycorrhizal fungi, medicinal plants, mycorrhizal colonization, spore density, black cumin, anise.

\section{INTRODUCTION}

Mycorrhiza are a symbiotic relationship between the fungus and plant roots (Frank, 1885). AMF are associated with almost all plants in nature (Hayman, 1982) and are ubiquitous. Symbiosis of Mycorrhizae is one of the best known symbiotic systems in plants which are observable in most ecosystems and most of plants have at least one type of Mycorrhiza (Ardakani et al., 2000). Almost all

\footnotetext{
* Corresponding author: Tel. : +201062600273 E-mail address: dinaibrahim73@yahoo.com
}

land plants including cereals, legumes, millets, plantations and horticultural crops ornamental and medicinal plants and forest trees are reported to be host of AMF (Chandra and Kehri, 2006).

The mycorrhizal symbiosis between fungi and plant behaves as a three phase heterogeneous interaction where all components, the soil, the plant and the fungus are in contact. Each component affects mycorrhizae in different ways. But the main drivers of symbiosis are the 
degree of dependence of the plant on the AMF, the fungus efficiency to establish symbiosis and the phosphorus $(\mathrm{P})$ availability in the soil. Also, it was found that mycorrhizae increase nutrients absorption distance around roots which lead to increasing of root colonization and increasing of nutrition uptake (Smith and Read, 2008).

AMF symbiotic association plays a major role in nutrient acquisition (Mosse, 1981). AMF play a key role in soil fertility and plant nutrition. They enhance the uptake and translocation of mineral nutrients - mainly $\mathrm{P}, \mathrm{N}, \mathrm{S}, \mathrm{K}, \mathrm{Ca}, \mathrm{Fe}$, $\mathrm{Cu}$ and $\mathrm{Zn}$ from soil of host plants (Giovannetti and Avio, 2002; Smith and Read, 2008). AMF are known to provide phosphorus at very low concentration to the host plants. Also, AMF increase the effective absorbing surface of the host root by as much as ten times (Mehrvarz et al., 2008; Soleimanzadeh, 2010; Alizadeh, 2012).

Mycorrhizae is a multi-functional fungus in agricultural ecosystems which enhances the soil physical quality (with improvement of hyphae), chemical quality (enhanced absorbing nutrients) and biological quality (with development of nutritional channels) (Cardoso and Kuyper, 2006). Among the biotic factors, the inoculation with AMF can influence the production of active ingredients in medicinal and aromatic plants (Kapoor et al., 2002; Karagiannidis et al., 2011).

Therefore, the present work was aimed to investigate the effect of inoculation of AMF and some beneficial microbes on root colonization of some medicinal plants and spore density in the rhizosphere of these plants under different levels of labeled nitrogen fertilization $\left({ }^{15} \mathrm{~N}\right)$ in sandy loam soil.

\section{MATERIALS AND METHODS}

\section{Occurrence of Amf in the Rhizosphere Samples of Medicinal Plants}

\section{Samples collection of plants with roots and soil rhizosphere}

Soil samples were collected from the rhizosphere of 22 medicinal plants at Sekem Company Farm, Belbase, Sharkia District, Egypt to study the variations of AMF infection in these plants. Samples were air dried and then preserved in clean plastic bags. Pebbles and other unwanted matters were removed from the spread samples. Large lumps were broken with wooden roller or hand. After grinding soil samples were sieved and fine soils were stored in clean plastic poly propylene bags with labeling tag for mycorrhizal fungal spore estimation and soil physical, chemical, and microbiological analyses at room temperature.

\section{Isolation of AMF by wet-sieving and decanting technique}

Quantification and separation of AMF spores from soil sample each medicinal plant rhizosphere was done by using wet sieving and decanting method (Gerdemann and Nicolson, 1963). This technique was used for sieving the coarse particles of the soil and retaining AMF spores and organic particles on sieves of different sizes. For isolation of the spores, $100 \mathrm{~g}$ of soil were added to $1000 \mathrm{ml}$ of water in a large beaker, then stirred well on magnetic stirred and settled until all the aggregates dispersed to leave a uniform suspension. The suspension was passed through $710 \mu \mathrm{m}$ sieves decanted through $425 \mu \mathrm{m}, 250 \mu \mathrm{m}, 150 \mu \mathrm{m}, 125 \mu \mathrm{m}, 75 \mu \mathrm{m}, 63$ $\mu \mathrm{m}$ and $45 \mu \mathrm{m}$ sieves, consecutively. The contents on the sieves were transferred to clean beaker, suspended in water and adjusted to a known volume $100 \mathrm{ml}$. One $\mathrm{ml}$ was taken from the suspension with Pasteur pipette and transferred into Petri-dish containing a Millipore filter to count AMF spores under a dissecting microscope10-40x. The number of spores was expressed as spores $/ 100 \mathrm{~g}$ of rhizosphere soil sample.

\section{Identification of AMF spore}

AMF spores were identified according to the morphological characteristics described by Gerdemann and Trappe (1974) and Trappe (1982). For identification and nomenclature INVAM's19 World Wide Web site at http:// invam.caf.edu/methods/mycorrhizae was used.

\section{Estimation of root colonization}

The root samples were cleaned and stained with trypan blue according to modified method of the Phillips and Hayman (1970) as follows: Roots were carefully washed to remove soil and other particles in running tap water and cut into small $(1 \mathrm{~cm})$ pieces. Roots were immersed in $10 \% \mathrm{KOH}$ solution and heated for $10 \mathrm{~min}$ at 80 - 
$90^{\circ} \mathrm{C}$ in water bath, Then, root pieces were washed several times with distilled water and treated with $1 \% \mathrm{HCl}$ for 3-4 min. Root pieces were stained with $0.05 \%$ trypan blue and left in water bath for $5-10 \mathrm{~min}$ at $80-90^{\circ} \mathrm{C}$, then placed on clean glass slide with few drops of glycerol. Slides were observed under the microscope to score for any structures associated with mycorrhizal fungi, like hyphae, vesicles or arbuscles in each segment. The percentage of AM fungal colonization was assessed by using the following formula:

Percentage of infection $=$

No. of root segments infected

Total No. of root segments observed

AM fungal colonization was visualized in the root tissues of each plant species using frequency distribution method proposed by Biermann and Linderman (1981).

\section{Effect of Inoculation with AMF and some Beneficial Microbes on Root Colonization and Spore Density of Black Cumin and Anise Plants under Different Labeled Nitrogen $\left({ }^{15} \mathrm{~N}\right)$ Fertilization Doses}

Pot experiments were set up from November 2015 to April 2016 to evaluate plant mycorrhization either solely or in combination with a symbiotic $\mathrm{N}_{2}$ fixer and phosphate dissolving bacteria affecting root colonization and spore density of black cumin and anise plants.

Plastic pots with $30.0 \mathrm{~cm}$ height, $30.0 \mathrm{~cm}$ diameter were used for cultivation of the above mentioned plants using sandy loam soil. The unsterile soil and mycorrhizal spore density was (77/100g of soil). Each pot was filled up to $8 \mathrm{~kg}$ of air-dried soil. The plants were irrigated every two days with $250 \mathrm{ml}$ tap water.

\section{Preparation of inocula}

\section{Mycorrhizal inoculants}

Soil samples containing AMF spores extracted (as previously described) from the rhizosphere of the medicinal plants grown on sandy loam soil of Sekem Company Farm were thoroughly mixed. Soil contained AMF (10 spore/g) was used as standard inoculum in all experiment. The mycorrhizal inoculum was added at rate of $100 \mathrm{~g}$ per pot. The major population was $80 \%$ Glomus spp., $15 \%$ Gigospora sp., and few from Aculospora sp. and Sctellospora sp.

\section{Bacterial inoculants}

Phosphate dissolving bacteria (Bacillus megatherium var phosphaticum) and, a symbiotic $\mathrm{N}_{2}$ fixers (Azotobacter chroococcum) peat based inoculants were provided by Agricultural Microbiology Department, Soil, Water and Environment Research Institute, Agriculture Research Center (ARC), Ministry of Agriculture and Land Reclamation, Giza, Egypt.

\section{Medicinal plants (host genotype)}

Seeds of two medicinal and aromatic plants were kindly provided by Sekem company:-

a-Anise (Pimpinella anisum L.) belonging to Apiaceae family.

b-Black cumin (Nigella sativa L.), plant belonging to Ranunculaceae family.

\section{Soil}

Unsterile sandy loam soil was used in this investigation. The soil was collected from the field of Soil and Water Research Department, Nuclear Research Center, Egyptian Atomic Energy Authority, Inshas, Egypt. Physical and chemical characteristics of the experimental soil sample are presented in Table 1. Soil analysis was carried out according to Estefen et al. (2013).

\section{Fertilizers}

Potassium and phosphorus fertilizers were added at recommended doses in the experiment before planting. Nitrogen fertilizer was applied at recommended dose rates of $400 \mathrm{~kg}$ fad. $^{-1}$ ammonium sulfate for black cumin and $200 \mathrm{~kg}$ $\mathrm{fad}^{-1}$ ammonium sulfate for anise. It was added after one month from cultivation on three rates zero, 50 and $100 \%\left(\mathrm{~N}_{0}, \mathrm{~N}_{1}\right.$ and $\mathrm{N}_{2}$, respectively) recommended doses. Nitrogen fertilizer was applied in the labeled ammonium sulfate $\left({ }^{15} \mathrm{NH}_{4}\right)_{2} \mathrm{SO}_{4}$ form with enrichment $2 \%{ }^{15} \mathrm{~N}$ atom excess (Table 2).

The experiments for nitrogen fertilization $\left({ }^{15} \mathrm{~N}\right)$ were arranged in randomized complete block design with three replicates and 6 plants pot $^{-1}$ for each treatment. Plants and rhizosphere 
Table 1. Physical and chemical properties of the experimental soil sample

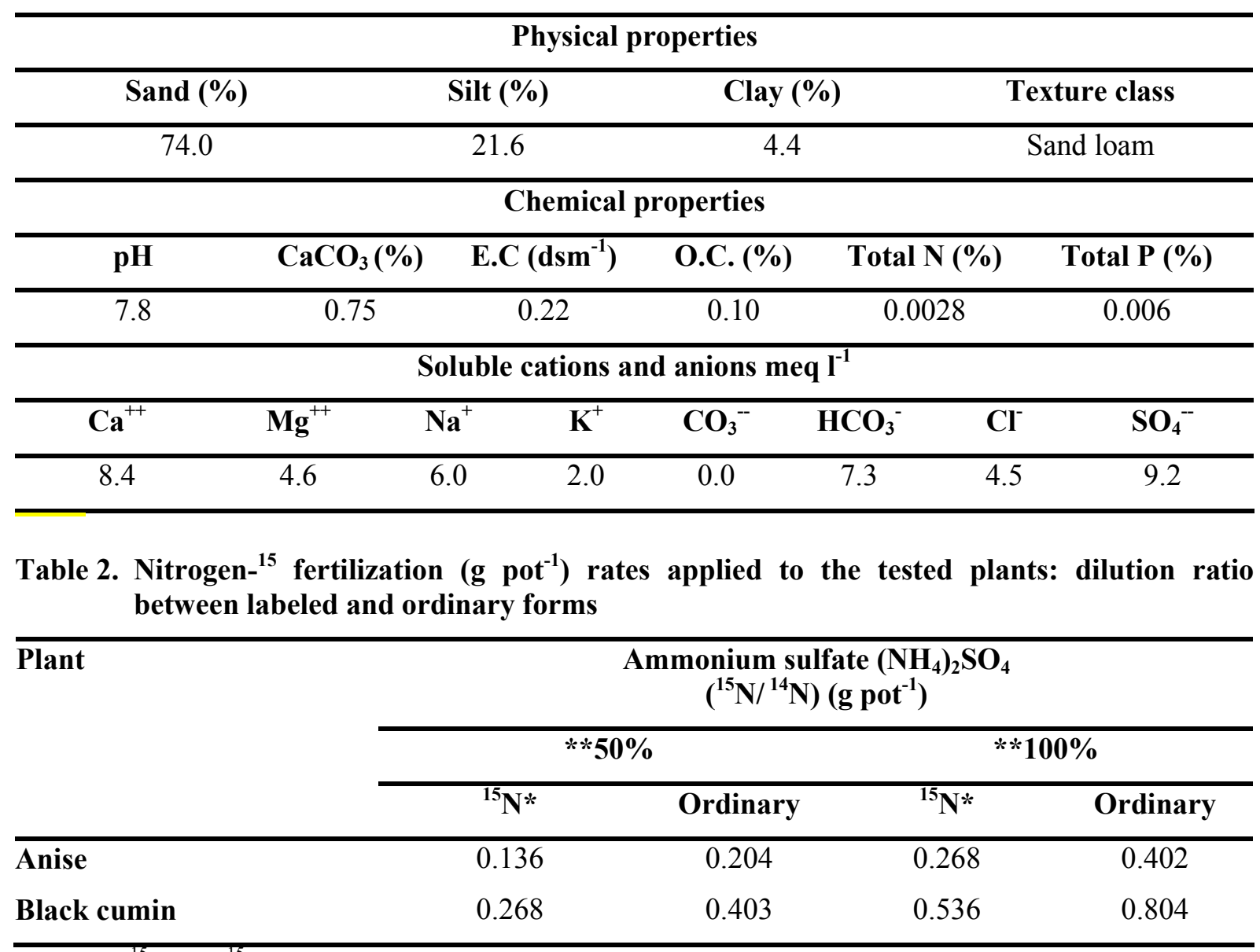

* Labeled ${ }^{15} \mathrm{~N}\left(2 \%{ }^{15} \mathrm{~N}\right.$ a.e. $),{ }^{* *}$ from the recommended rate.

soil samples were taken at intervals of 30,60 and 120 days of planting to determine percentage of mycorrhizal infection on black cumin and anise plants. Mycorrhizal spore density was determined at the end of experiment.

The experimental treatments were:

1. $\mathrm{M}_{0}$ : Control (without microbial inoculation)

2. $\mathrm{M}_{1}$ : Inoculated with arbuscular mycorrhizal fungi (AMF)

3. $\mathrm{M}_{2}$ : Azotobacter chroococcum

4. $\mathrm{M}_{3}$ : Bacillus megatherium

5. $\mathrm{M}_{4}: \mathrm{AMF}+$ Azotobacter chroococcum

6. $\mathrm{M}_{5}: \mathrm{AMF}+$ Bacillus megatherium

7. $\mathrm{M}_{6}: \mathrm{AMF}+$ Azotobacter chroococcum + Bacillus megatherium

\section{RESULTS AND DISCUSSION}

\section{Occurrence of AMF in the Rhizosphere of some Medicinal Plants}

The distribution of AMF in different medicinal plants in Sekem farm soil has been studied in 22 medicinal plants. It is well known that the occurrence of AMF is affected by the climate, soil type and host plant.

Results in Table 3 indicate that all the medicinal plants studied showed AMF associations. The mycorrhizal association changed among various plant species and there was a significant difference in root colonization. AM Fungal colonization and diversity were noted in rhizosphere soil. Mycorrhizae colonization was indicated by the presence of hyphal networks, arbuscules, vesicles and 
Table 3. Occurence of AMF in 22 rhizospere samples of the medicinal plants

\begin{tabular}{|c|c|c|c|c|}
\hline Name of the plant species & $\begin{array}{l}\text { Family } \\
\text { name }\end{array}$ & $\begin{array}{l}\text { Type of } \\
\text { infection }\end{array}$ & $\begin{array}{c}\text { Infection } \\
\text { percentage }\end{array}$ & $\begin{array}{c}\text { Spore population } \\
\text { per } 100 \text { g soil }\end{array}$ \\
\hline$\overline{\text { Borage (Borago officinalis L.) }}$ & Boraginaceae & $\overline{H V}$ & $38.67 \pm 1.20$ & $261 \pm 2.03$ \\
\hline Cornflower (Centaurea cyamus L.) & Asteraceae & HA & $54.00 \pm 0.58$ & $192 \pm 1.73$ \\
\hline Pot marigold (Clandula officinalis L.) & Asteraceae & HAV & $58.67 \pm 0.88$ & $273 \pm 2.03$ \\
\hline Cumin (Cuminum cyminum L.) & Apiaceae & HV & $53.00 \pm 0.58$ & $199 \pm 2.31$ \\
\hline Lemon grass (Cymbopgon citratus L.) & Poaceae & HV & $58.33 \pm 0.88$ & $103 \pm 2.61$ \\
\hline Milk thistles (Silybum marianum L.) & Asteraceae & HA & $19.00 \pm 1.16$ & $221 \pm 3.18$ \\
\hline Fennel (Foeniculum vulgare L.) & Apiaceae & HAV & $70.50 \pm 0.87$ & $261 \pm 1.45$ \\
\hline Rock-rose (Helianthemum vulgar L.) & Cistaceae & HA & $45.07 \pm 0.64$ & $262 \pm 2.34$ \\
\hline Lavender (Lavandula angustifolia $\mathrm{L}$.) & Lamiaceae & HV & $66.80 \pm 1.17$ & $220 \pm 2.03$ \\
\hline Chamomile (Matricaria chamomilla L.) & Asteraceae & HV & $60.00 \pm 1.16$ & $106 \pm 3.18$ \\
\hline Lemon balm (Melissa officinalis L.) & Lamiaceae & HAV & $54.77 \pm 0.91$ & $248 \pm 1.77$ \\
\hline Peppermint (Mentha piperita L.) & Lamiaceae & HV & $46.20 \pm 0.99$ & $212 \pm 2.34$ \\
\hline Spearmint (Mentha viridis L.) & Lamiaceae & HV & $56.00 \pm 1.16$ & $221 \pm 2.34$ \\
\hline Black cumin (Nigella sativa L.) & Ranunculaceae & HA & $77.00 \pm 1.16$ & $269 \pm 2.65$ \\
\hline Sweet Basil (Ocimum bacillicum L.) & Lamiaceae & HV & $26.13 \pm 0.70$ & $228 \pm 1.73$ \\
\hline Marjoram (Originum majorana L.) & Lamiaceae & HV & $45.03 \pm 0.55$ & $282 \pm 1.77$ \\
\hline Rose Geranium (Pelargonium graveolus L.) & Geraniaceae & HA & $46.00 \pm 0.58$ & $122 \pm 1.77$ \\
\hline Parsley (Petroselinum crispum L.) & Apiaceae & HA & $18.17 \pm 0.60$ & $338 \pm 1.16$ \\
\hline Anise (Pimpinella anisum L.) & Apiaceae & HV & $72.00 \pm 1.16$ & $368 \pm 1.16$ \\
\hline Rosemary (Rosmarinus officinalis L.) & Lamiaceae & HV & $59.40 \pm 0.87$ & $310 \pm 1.77$ \\
\hline Sage (Salvia officinalis L.) & Lamiaceae & HA & $47.17 \pm 1.17$ & $186 \pm 1.73$ \\
\hline Thyme (Thymus vulgaris L.) & Lamiaceae & HV & $59.13 \pm 0.47$ & $201 \pm 2.34$ \\
\hline
\end{tabular}

Values are mean of three replicates \pm SE.

H: Hyphae; A: Arbuscules; V: Vesicles

endospores (Fig. 1). The maximum root infection was observed in black cumin being $77 \%$ which belongs to the family Ranunculaceae and lowest root infection was recorded as $18.17 \%$ in parsley which belongs to the family Apiaceae. The obtained results agree with Warner and Mosse (1980) who found that the AMF associations depends on root morphology, metabolism and rate of plant growth as well as specific soil plant system in term of chemical nature of root exudates.

The present result also showed that all medicinal plants have rhizosphere soil spore density and root colonized. The highest spore population was recorded as $368 / 100 \mathrm{~g}$ soil in anise plant, which belongs to the family Apiaceae. The lowest spore population showing $103 / 100 \mathrm{~g}$ soil in lemon grass plant which belongs to the family Poaceae. The major population was represented as Glomus species followed by Gigospora, Aculospora, and Sctellospora. The obtained results are in agreement with the findings mentioned by Koul et al. (2012) who found that the AMF endophytes are widespread in all the soils investigated but varied in both number and the type of spores and 

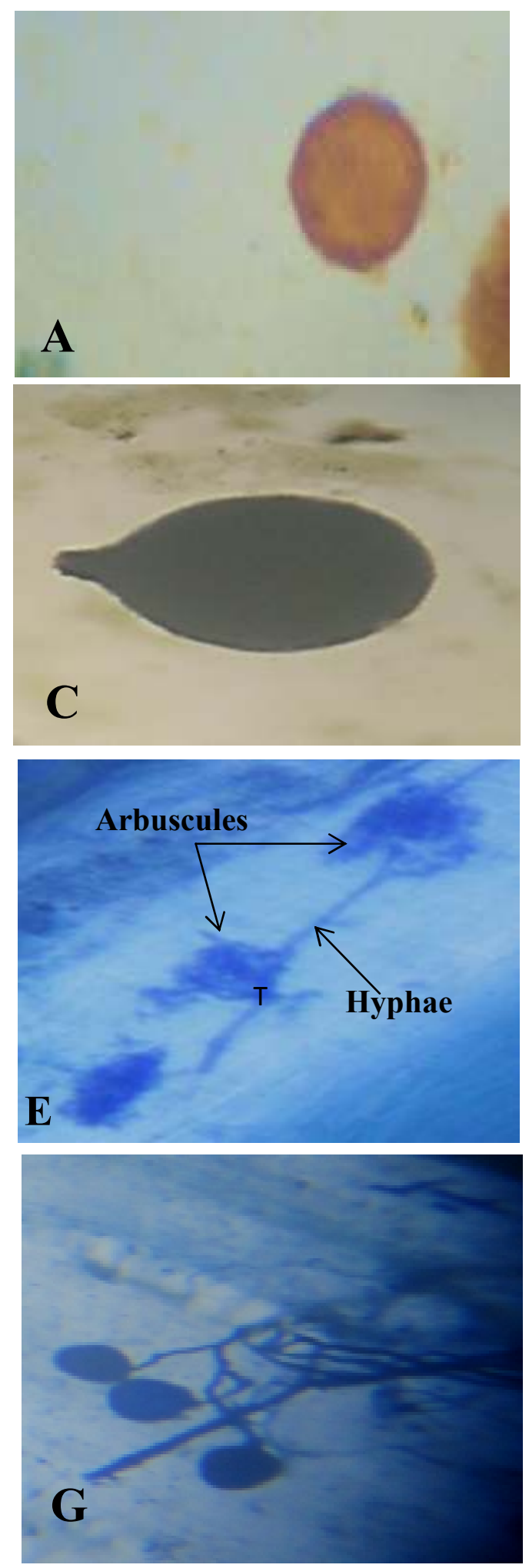
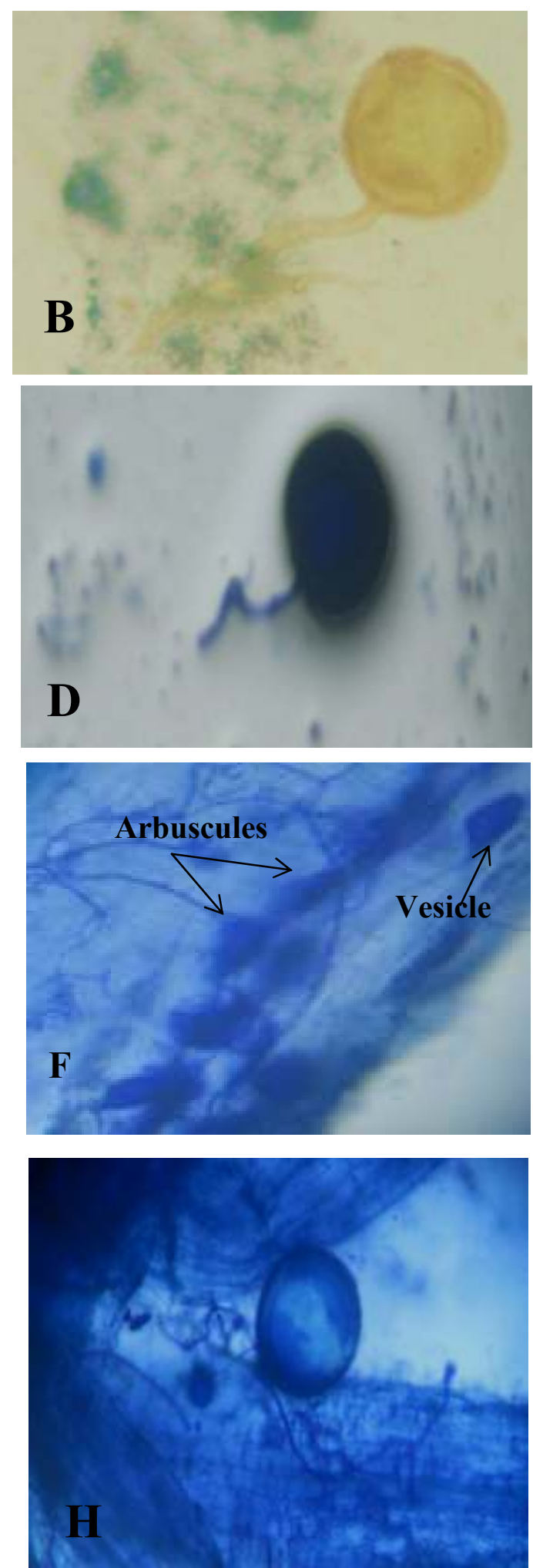

Fig. 1. Light microscopic photograph of AMF extracted from different medicinal plants (40X)
A: Glomus mosseae spore
B: Glomus clarum spore
D: Glomus spp. with hyphal branching
F: Arbuscular, vesicle and intraradical hyphae
C: Glomus constrictum spore
E: Arbuscular and intraradical hyphae G \& H: Intraradical hyphae and vesicles 
sporocarps. They also found that AMF spore count showed no significant or positive correlation with the root colonization percentage. According to Mehrota (2005), AMF in the Fabaceas and Poaceas have great ability to make associations in normal crop conditions. AMF association's records high occurrence also with medicinal and aromatic plants (Urcoviche et al., 2014).

Detailed photographic presented in Fig. 1 illustrated the AMF spores and their associations with root system. Table 4 show the difference between Glomus sp. isolates. Different varieties of spores were isolated from different medicinal plants in this study. This study showed that biodiversity of arbuscular mycorrhizal fungi differed in different plants. Presence of Glomus in different types can lead to an assumption that various species of Glomus might have developed a good adaptive mechanism of symbiosis with different host medicinal plants according to Heijden et al. (1998).

The obtained results also agree with Sarwade et al. (2011) who found that Glomus species as major impact on the host plants even under any environmental conditions as presented climatic and chemical factors in their study area. The predominance of various Glomus spp. appeared to be general observation reported under curtained ecosystem by others also including medicinal plants (Ram and Bhadauria, 2009; Koul et al., 2012; Muthuraj et al., 2014). Glomus indicated high adaptive mechanism for associations with various medicinal plants.

Effect of Inoculation with AMF and some Beneficial Microbes on Root Colonization And Spore Density of Black Cumin and Anise Plants Under Different Labeled Nitrogen $\left({ }^{15} N\right)$ Doses

\section{Mycorrhizal root infection}

\section{Black cumin plants}

The effect of inoculation with AMF individually or combined with Azotobacter chroococcum or Bacillus megatherium and mixture of them on Mycorrhizal colonization in Nigella sativa roots under different labeled nitrogen doses was evaluated. Mycorrhizae root infection of black cumin was examined after 30 , 60 and 120 days of cultivation, as seen in Table 5 and Fig. 2.

Results presented in Table 5 clearly show that AMF root colonization increased significantly with AMF inoculation in all inoculated treatments. The percentage of root colonization after 30 days, in the absence of nitrogen fertilizer $\left({ }^{15} \mathrm{~N}_{0}\right)$ reached their maximal levels being $42.00 \%$ when inoculated with mixture of AMF, Az.chroococcum and B.megatherium $\left(\mathrm{M}_{6}\right)$ followed by $40.67 \%$ for each of $\mathrm{M}_{4}$ and $\mathrm{M}_{5}$ treatments. It was also found that inoculated plants with AMF individually recorded $38.33 \%$ compared with the control $(6 \%)$ in the same nitrogen dose. Also, with applying half the recommended nitrogen dose $\left({ }^{15} \mathrm{~N}_{1}\right)$, the maximum level being $50.33 \%$ was obtained in the combination treatment $\left(\mathrm{M}_{6}\right)$ followed by $47.33,44.67$ and $43.67 \%$ expressed on $\mathrm{M}_{4}, \mathrm{M}_{5}$ and $\mathrm{M}_{1}$, respectively compared with the control $(8 \%)$ in the same ${ }^{15} \mathrm{~N}$-fertilizer dose. In the case of full recommended nitrogen dose $\left({ }^{15} \mathrm{~N}_{2}\right)$, inoculation with AMF alone or in combination increased AMF root colonization and the maximum was $50 \%$ with $\left(\mathrm{M}_{6}\right)$ followed by $47.00,44.67$ and $44.67 \%$ expressed on $\mathrm{M}_{4}, \mathrm{M}_{5}$ and $\mathrm{M}_{1}$, respectively compared with the control $(10 \%)$ in the same ${ }^{15} \mathrm{~N}$-fertilizer dose. Commonly, the highest infection level being $50.33 \%$ at combination $\left(\mathrm{M}_{6} \mathrm{~N}_{1}\right)$ while control $\left(\mathrm{M}_{0} \mathrm{~N}_{0}\right)$ showed the lowest infection level being $(6.0 \%)$.

On the other hand, the percentage of root colonization after 60 days, in the absence of nitrogen fertilizer dose $\left(\mathrm{N}_{0}\right)$ reached their maximal levels, being $59.67 \%$, when inoculated with mixture of AMF, Az.chroococcum and B.megatherium $\left(\mathrm{M}_{6}\right)$ followed by $57.33,49.0$ and $48.67 \%$ for the $M_{4}, M_{1}$ and $M_{5}$ treatments, respectively compared with the un inoculated control giving $9.67 \%$ in the same ${ }^{15} \mathrm{~N}$ dose. On using half recommended nitrogen dose $\left(\mathrm{N}_{1}\right)$ the maximum level, $80.67 \%$, was obtained in the combination treatments $\left(\mathrm{M}_{6}\right)$ followed by 74.0 , 71.0 and $67.0 \%$ expressed on $\mathrm{M}_{4}, \mathrm{M}_{5}$ and $\mathrm{M}_{1}$, respectively compared with control $13.67 \%$ in the same $\mathrm{N}$-fertilizer dose. In case of full recommended nitrogen dose $\left(\mathrm{N}_{2}\right)$ inoculation with AMF alone or in combination significantly increased AMF root colonization and the maximum was $82.33 \%$ with $\left(\mathrm{M}_{6}\right)$ followed by 73.0, 71.0 and $67.0 \%$ with $\mathrm{M}_{4}, \mathrm{M}_{5}$ and $\mathrm{M}_{1}$, respectively compared with the control $16.0 \%$ in the same ${ }^{15} \mathrm{~N}$-fertilizer dose. The highest AMF root infection percentage after 60 days being $82.33 \%$ was recorded in the treatment where combination inoculated with AMF, Az. chroococcum and B.megatherium was used with full recommended nitrogen dose compared with the control which was $9.67 \%$ without ${ }^{15} \mathrm{~N}$ fertilizer. 
Table 4. Microscopic characters of AMF spores associated with medicinal plants

\begin{tabular}{|c|c|c|c|c|}
\hline$\overline{\mathrm{AMF}}$ & $\begin{array}{l}\text { Spore size } \\
(\mu \mathrm{m})\end{array}$ & $\begin{array}{l}\text { Spore } \\
\text { layer }\end{array}$ & Colour & Other descriptions \\
\hline Glomus spp. & & & & Sporocarp containing chlamydospores \\
\hline G. mosseae & 200 & 3 & $\begin{array}{l}\text { Brown to orange } \\
\text { brown }\end{array}$ & $\begin{array}{l}\text { Hyphae are double layered. } \\
\text { Spore globose to sub-globose }\end{array}$ \\
\hline G. constrictum & $\begin{array}{c}110-130 x \\
150-160\end{array}$ & 2 & $\begin{array}{l}\text { Brownish orange } \\
\text { to dark brown }\end{array}$ & $\begin{array}{l}\text { Subtending hyphae straight or curved, usually } \\
\text { markedly constricted at the spore base. } \\
\text { Globose to subglobose, sometimes ovoid }\end{array}$ \\
\hline G. clarum & $80-150 \mu \mathrm{m}$ & 3 & $\begin{array}{l}\text { Cream to pale } \\
\text { yellow }\end{array}$ & $\begin{array}{l}\text { Forms hypogeous sporocarps, spores in } \\
\text { sporocarps mostly }\end{array}$ \\
\hline
\end{tabular}

Table 5. Effect of inoculation with AMF and/or some beneficial microbes under labeled nitrogen $\left({ }^{15} \mathrm{~N}\right)$ fertilization on mycorrhizal root infection after 30,60 and 120 days from cultivation of black cumin plants

\begin{tabular}{|c|c|c|c|c|c|c|c|c|c|}
\hline \multicolumn{10}{|c|}{ Infection percentage } \\
\hline \multirow[t]{3}{*}{ Treatment } & \multicolumn{3}{|c|}{ After 30 days } & \multicolumn{3}{|c|}{ After 60 days } & \multicolumn{3}{|c|}{ After 120 days } \\
\hline & \multicolumn{3}{|c|}{ Nitrogen $\left({ }^{15} \mathrm{~N}\right)$} & \multicolumn{3}{|c|}{ Nitrogen $\left({ }^{15} \mathrm{~N}\right)$} & \multicolumn{3}{|c|}{ Nitrogen $\left({ }^{15} \mathrm{~N}\right)$} \\
\hline & $\mathbf{N}_{0}$ & $\mathbf{N}_{1}$ & $\mathbf{N}_{2}$ & $\mathbf{N}_{0}$ & $\mathbf{N}_{1}$ & $\mathbf{N}_{2}$ & $\mathbf{N}_{0}$ & $\mathbf{N}_{1}$ & $\mathbf{N}_{2}$ \\
\hline$\overline{\mathbf{M}_{0}}$ & 6.00 & 8.00 & 10.00 & 9.67 & 13.67 & 16.00 & 15.67 & 22.00 & 24.67 \\
\hline $\mathbf{M}_{1}$ & 38.33 & 43.67 & 44.67 & 49.00 & 67.00 & 67.00 & 58.00 & 74.00 & 73.33 \\
\hline $\mathbf{M}_{2}$ & 9.00 & 12.00 & 15.00 & 18.67 & 23.33 & 24.67 & 27.33 & 31.00 & 33.33 \\
\hline $\mathbf{M}_{3}$ & 9.00 & 12.33 & 15.00 & 15.67 & 21.00 & 25.00 & 25.33 & 28.00 & 28.33 \\
\hline $\mathbf{M}_{4}$ & 40.67 & 47.33 & 47.00 & 57.33 & 74.00 & 73.00 & 65.33 & 78.33 & 75.67 \\
\hline $\mathbf{M}_{5}$ & 40.67 & 44.67 & 44.67 & 48.67 & 71.00 & 71.00 & 61.33 & 73.67 & 74.00 \\
\hline $\mathbf{M}_{6}$ & 42.00 & 50.33 & 50.00 & 59.67 & 80.67 & 82.33 & 71.67 & 83.67 & 82.33 \\
\hline Mean & 26.52 & 31.19 & 32.33 & 36.95 & 50.10 & 51.29 & 46.38 & 55.81 & 55.95 \\
\hline LSD 0.05 & M:1.363 & N: 892; & M: 2.36 & 4:2.41; I & $1.58 ; \mathrm{N}$ & M: 4.17 & M:1.72 & $\mathrm{N}: 1.13$ & NM:2.98 \\
\hline
\end{tabular}

Note: $\mathrm{N}_{0}, \mathrm{~N}_{1}$ and $\mathrm{N}_{2}$ are zero $\%, 50 \%$ and $100 \%$ Nitrogen $\left(\mathrm{N}^{15}\right)$, respectively of recommended dose.

$\mathrm{M}_{0}$ : control, $\mathrm{M}_{1}$ : AMF, $\mathrm{M}_{2}$ : Azotobacter chroococcum, $\mathrm{M}_{3}:$ Bacillus megatherium, $\mathrm{M}_{4}: \mathrm{AMF}$ Az.chroococcum, $\mathrm{M}_{5}$ : $\mathrm{AMF}+$ B.megatherium and $\mathrm{M}_{6}$ : $\mathrm{AMF}+$ Az.chroococcum + B.megatherium 

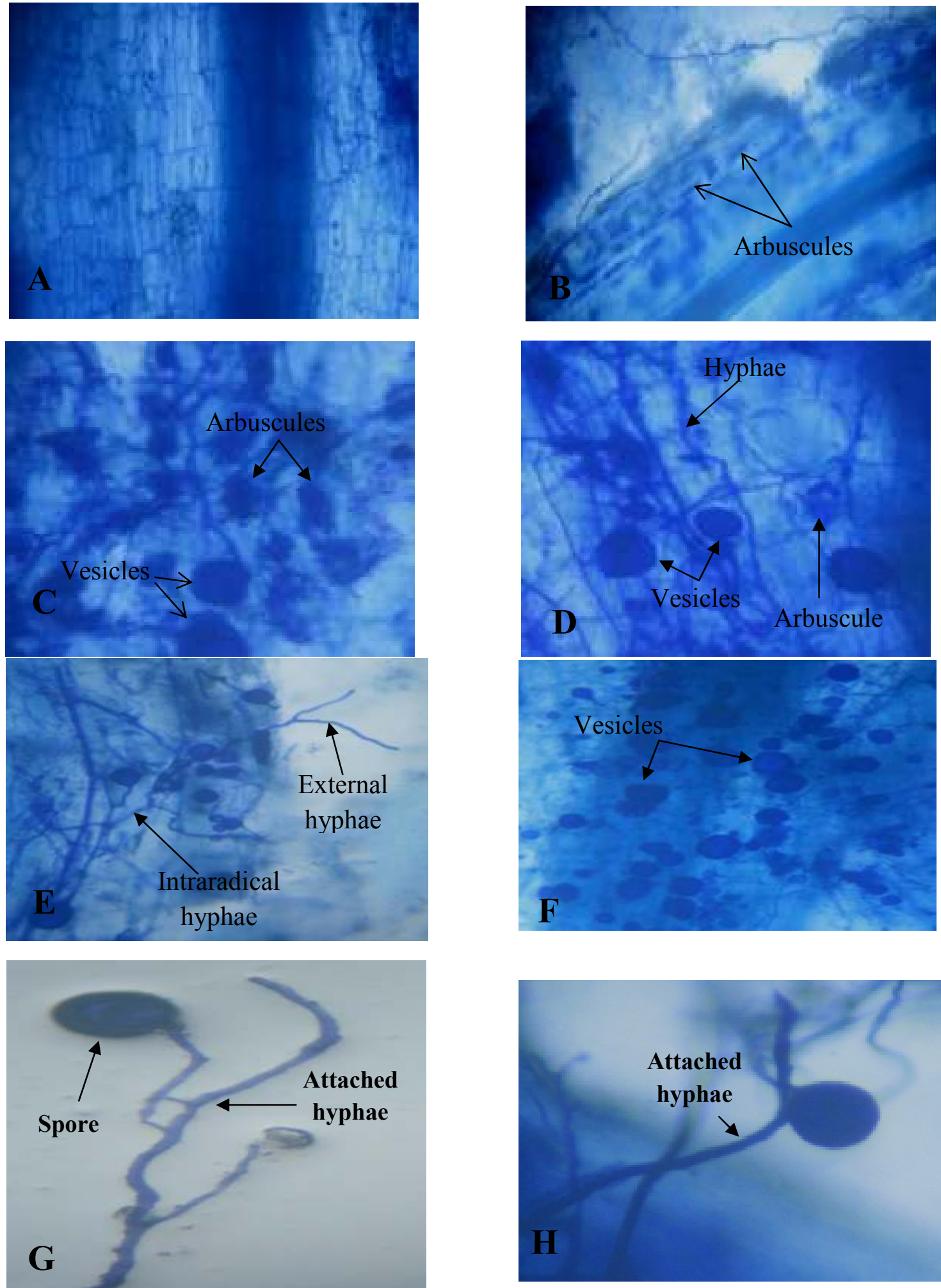

Fig. 2. Microscopic photographs showing root colonization in black cumin stained with trypan blue (40X)

A: Non mycorrhizal colonization

E \& F: Infection after 120 days
B: Infection after 30 days

C\&D: Infection after 60 days G\&H: Vesicle and intraradical hyphae 
AMF root infection percentage after 120 days in the absence of nitrogen fertilizer dose $\left({ }^{15} \mathrm{~N}_{0}\right)$ reached their maximal levels being $71.67 \%$ when inoculated with mixture of AMF, Az.chroococcum and B.megatherium $\left(\mathrm{M}_{6}\right)$ followed by 65.33 and $61.33 \%$ for the $\mathrm{M}_{4}$ and $\mathrm{M}_{5}$ treatments, respectively compared with the uninoculated control which was $15.67 \%$ in the same ${ }^{15} \mathrm{~N}$ dose. It was also found that inoculated plants with AMF alone without nitrogen giving $58.0 \%$ compared with the control $(15.67 \%)$ in the same dose. Also, with half recommended nitrogen dose $\left({ }^{15} \mathrm{~N}_{1}\right)$ the maximum level being $83.67 \%$ in the combination treatment $\left(\mathrm{M}_{6}\right)$ followed by $78.33,74.00$ and $73.67 \%$ expressed on $\mathrm{M}_{4}, \mathrm{M}_{1}$ and $\mathrm{M}_{5}$, respectively compared with the control $(22.00 \%)$ in the same N-fertilizer dose. In the case of full recommended nitrogen dose $\left({ }^{15} \mathrm{~N}_{2}\right)$ inoculation with AMF alone or in combination gave significant increases percentage for AMF root colonization and the maximum reached $82.33 \%$ with $\left(\mathrm{M}_{6}\right)$ followed by $75.67,74.00$ and $73.33 \%$ expressed on $\mathrm{M}_{4}$, $\mathrm{M}_{5}$ and $\mathrm{M}_{1}$, respectively compared with the control $(24.67 \%)$ in the same N-fertilizer dose. The maximal levels being $83.67 \%$ was obtained in treatment inoculated with AMF, Az.chroococcum and B.megatherium $\left(\mathrm{M}_{6}\right)$ when nitrogen was half of the recommended dose compared to the other treatments. It was also noticed that the percentage of infection in Nigella sativa plants increased significantly by increasing nitrogen fertilization $\left({ }^{15} \mathrm{~N}\right)$ levels compared with control.

Results showed also that the combined of AMF with bacterial inoculation treatments resulted in a higher AMF colonization in comparison with AMF as single inoculants ones. These results agree with Fitter and Garbaye (1994) who found that rhizobacteria increased the capacity of AMF to colonize the roots of plants. However, according to GianinazziPearson (1982), free-living bacteria such Azotobacter spp. and Azospirillum spp. can increase microbial populations in the rhizosphere of mycorrhizal plants. Production of mycorrhizal propagules (spores, hyphae and colonized roots) permits the inoculation of these organisms in plants growing in soils where AMF inoculum levels are reduced, and this is an important part of the process of soil microbiota recuperation (Smith and Read 1997). These results differ from those of Constantino et al. (2008) who reported that the combined inoculation of AMF and rhizobacteria resulted in a lower colonization in comparison with the treatments with AMF as a single inoculant.

\section{Anise plants}

The obtained results presented in Table 6 and Fig. 3 clearly show that mycorrhizae root

Table 6. Effect of inoculation with AMF and/or some beneficial microbes under labeled nitrogen $\left({ }^{15} \mathrm{~N}\right)$ fertilization on mycorrhizal root infection after 30,60 and 120 days from cultivation of anise plants

\begin{tabular}{|c|c|c|c|c|c|c|c|c|c|}
\hline \multicolumn{10}{|c|}{ Infection percentage } \\
\hline \multirow[t]{3}{*}{ Treatment } & \multirow{2}{*}{\multicolumn{3}{|c|}{$\begin{array}{c}\text { After } 30 \text { days } \\
\text { Nitrogen }\left({ }^{15} \mathrm{~N}\right)\end{array}$}} & \multirow{2}{*}{\multicolumn{3}{|c|}{$\begin{array}{c}\text { After } 60 \text { days } \\
\text { Nitrogen }\left({ }^{15} \mathrm{~N}\right)\end{array}$}} & \multirow{2}{*}{\multicolumn{3}{|c|}{$\begin{array}{l}\text { After } 120 \text { days } \\
\text { Nitrogen }\left({ }^{15} \mathrm{~N}\right)\end{array}$}} \\
\hline & & & & & & & & & \\
\hline & $\mathbf{N}_{0}$ & $\mathrm{~N}_{1}$ & $\mathrm{~N}_{2}$ & $\overline{\mathbf{N}_{0}}$ & $N_{1}$ & $\mathbf{N}_{2}$ & $\overline{N_{0}}$ & $\mathrm{~N}_{1}$ & $\mathbf{N}_{2}$ \\
\hline$\overline{\mathbf{M}_{0}}$ & 5.00 & 6.66 & 7.33 & 9.00 & 13.33 & 13.33 & 10.67 & 15.33 & 14.67 \\
\hline $\mathbf{M}_{1}$ & 27.00 & 34.66 & 36.66 & 38.67 & 58.33 & 58.00 & 40.33 & 68.00 & 71.00 \\
\hline $\mathbf{M}_{2}$ & 9.33 & 12.33 & 12.00 & 15.67 & 21.33 & 22.33 & 16.67 & 24.00 & 24.33 \\
\hline $\mathbf{M}_{3}$ & 8.66 & 14.00 & 13.00 & 16.00 & 21.67 & 22.67 & 16.33 & 24.00 & 23.33 \\
\hline $\mathbf{M}_{4}$ & 30.33 & 34.33 & 38.00 & 43.33 & 65.67 & 65.00 & 46.00 & 71.33 & 72.33 \\
\hline $\mathbf{M}_{5}$ & 31.33 & 34.00 & 37.00 & 44.33 & 63.67 & 64.00 & 46.67 & 70.00 & 70.67 \\
\hline $\mathbf{M}_{6}$ & 32.66 & 36.66 & 38.66 & 50.33 & 70.33 & 66.67 & 52.33 & 76.67 & 76.33 \\
\hline \multirow{2}{*}{$\begin{array}{l}\text { Mean } \\
\text { LSD 0.05 } \\
\end{array}$} & 20.62 & 24.66 & 26.09 & 31.05 & 44.90 & 44.57 & 32.71 & 49.90 & 50.38 \\
\hline & \multicolumn{3}{|c|}{ M:1.19; N:1.56; NM: 2.06} & \multicolumn{3}{|c|}{ M:3.03; N:1.99; NM: 5.26} & \multicolumn{3}{|c|}{$\mathrm{M}: 3.14 ; \mathrm{N}: 2.05 ; \mathrm{NM}: 5.44$} \\
\hline
\end{tabular}

Note: $\mathrm{N}_{0}, \mathrm{~N}_{1}$ and $\mathrm{N}_{2}$ are zero $\%, 50 \%$ and $100 \%$ Nitrogen $\left(\mathrm{N}^{15}\right)$ respectively from recommended dose.

$\mathrm{M}_{0}$ : control, $\mathrm{M}_{1}$ : AMF, $\mathrm{M}_{2}$ : Azotobacter chroococcum, $\mathrm{M}_{3}$ : Bacillus megatherium, $\mathrm{M}_{4}$ : $\mathrm{AMF}+$ Az.chroococcum, $\mathrm{M}_{5}: \mathrm{AMF}+$ B.megatherium and $\mathrm{M}_{6}: \mathrm{AMF}+$ Az.chroococcum + B.megatherium 

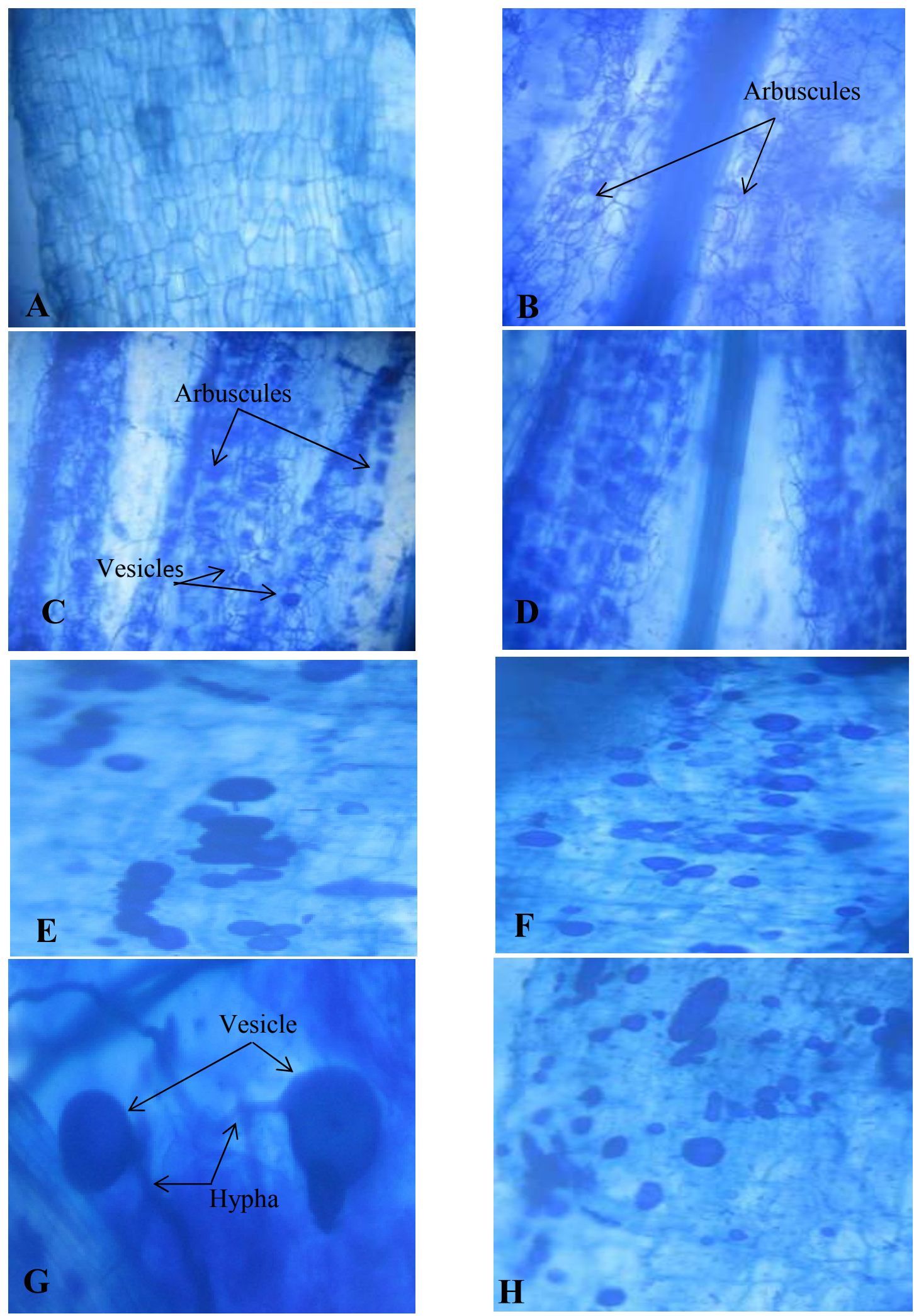

Fig. 3. Microscopic photographs showing root colonization in anise stained with trypan blue (40X)

A: Non mycorrhizal colonization C\&D: Infection after 60 days

B: Infection after 30 days

E to H: Infection after 120 days 
colonization of anise behaved the same general trend of black cumin. The percentage of root colonization after 30 days, in the absence of nitrogen fertilizer dose $\left(\mathrm{N}_{0}\right)$, the maximal levels was $32.66 \%$ when inoculated with AMF, Az.chroococcum and B.megatherium $\left(\mathrm{M}_{6}\right)$ compared with the un-inoculated control which was $5.00 \%$ in the same ${ }^{15} \mathrm{~N}$ dose. Also, with half recommended nitrogen dose $\left(\mathrm{N}_{1}\right)$ the maximum level being $36.66 \%$ reached in the combination treatment $\left(\mathrm{M}_{6}\right)$ compared with the control which was $6.66 \%$ in the same ${ }^{15} \mathrm{~N}$-fertilizer dose. In case of full recommended nitrogen dose $\left(\mathrm{N}_{2}\right)$ inoculated with AMF alone or in combination significantly increased AMF root colonization and the maximum was $38.66 \%$ with $\left(\mathrm{M}_{6}\right)$, while AMF individual being 36.66\% compared with control $7.33 \%$ in the same ${ }^{15} \mathrm{~N}$-fertilizer dose.

As well, after 60 days, when zero nitrogen fertilizer dose $\left(\mathrm{N}_{0}\right)$ was applied, the percentage of root colonization reached their maximal levels being $50.33 \%$ when inoculated with AMF, Az.chroococcum and B.megatherium $\left(\mathrm{M}_{6}\right)$ compared with control which was $9.0 \%$ in the same ${ }^{15} \mathrm{~N}$ dose. With half recommended nitrogen dose $\left({ }^{15} \mathrm{~N}_{1}\right)$ the maximum level reaching $70.33 \%$ was obtained in the combination treatment $\left(\mathrm{M}_{6}\right)$ compared with the control which was $13.33 \%$ in the same ${ }^{15} \mathrm{~N}$-fertilizer dose. In the case of full recommended nitrogen dose $\left({ }^{15} \mathrm{~N}_{2}\right)$ the maximum was $66.67 \%$ with $\left(\mathrm{M}_{6}\right)$ compared with control $\left(\mathrm{M}_{0}\right)$ which valued $13.33 \%$ in the same $\mathrm{N}$ fertilizer dose. AMF root infection percentage after 120 days at the absence of nitrogen fertilizer dose $\left(\mathrm{N}_{0}\right)$ reached their maximal levels being 52.33\% when inoculated with AMF, Az.chroococcum and B.megatherium $\left(\mathrm{M}_{6}\right)$ compared with the control which was $10.67 \%$ in the same ${ }^{15} \mathrm{~N}$ dose. With half recommended nitrogen dose $\left({ }^{15} \mathrm{~N}_{1}\right)$ the maximum level being $76.67 \%$ in the combination treatment $\left(\mathrm{M}_{6}\right)$ compared with control $15.33 \%$ in the same Nfertilizer dose. When added full recommended nitrogen dose $\left({ }^{15} \mathrm{~N}_{2}\right)$ the maximum percent was $76.33 \%$ with AMF, Az.chroococcum and B.megatherium $\left(\mathrm{M}_{6}\right)$ compared with control $(14.67 \%)$ in the same $\mathrm{N}$-fertilizer dose. The obtained photographic present in Fig. 3 illustrated that AMF stages in the anise plant from cultivation.

Generally, the maximal infection levels being $76.67 \%$ in treatment inoculated with AMF, $A z$. chroococcum and B.megatherium when nitrogen ${ }^{15} \mathrm{~N}_{1}$ was used in a half of the recommended dose after 120 days from cultivation compared to the other treatments. It was also noticed that the percentage of infection in anise plants increased significantly by inoculation with AMF individual or dual with Az.chroococcum or B.megatherium. Results revealed a significant interaction effect between nitrogen fertilization and mycorrhizae colonization on percentage infection in anise plant. According to Smith and Read (2008), the availability of $P$ in soils is the most important edaphic factor for the operation of the Mycorrhizal symbiosis. Moreover, this effect is of great value on the expected productivity of anise plants since percentage of infection plays an important role in the photosynthetic potentialities of anise plants, according to Corkid et al. (2002), Chen et al. (2005), Lestingi et al. (2007) and Ali et al. (2009).

\section{Mycorrhizae spore density in rhizosphere soil}

The density of mycorrhiza spores in the rhizosphere soil of black cumin and anise plants was determined at the end of the experiment. Obtained results presented in Table 7 clearly show that AMF spore density increased significantly with AMF and microbial inoculation in all treatments. The density of the rhizosphere mycorrhiza spores in the absence of nitrogen fertilizer dose $\left({ }^{15} \mathrm{~N}_{0}\right)$ reached their maximal levels being 346 spores $/ 100 \mathrm{~g}$ soil when inoculated with AMF, Az.chroococcum and B.megatherium $\left(\mathrm{M}_{6}\right)$ compared with the uninoculated control which gave 23 spores/100 g soil in the same ${ }^{15} \mathrm{~N}$ dose. Using half recommended nitrogen dose $\left({ }^{15} \mathrm{~N}_{1}\right)$ the maximum level obtained was 377 spores $/ 100 \mathrm{~g}$ soil in the combination treatments $\left(\mathrm{M}_{6}\right)$ followed by 344 and 334 spores $/ 100 \mathrm{~g}$ soil expressed on $\mathrm{M}_{1}$ and $\mathrm{M}_{5}$, respectively compared with the control 23 spores/100 g soil in the same ${ }^{15} \mathrm{~N}$-fertilizer dose. In case of full recommended nitrogen dose $\left({ }^{15} \mathrm{~N}_{2}\right)$ inoculation with AMF alone or with microbial combination increased significantly AMF spore density and the maximum reached 305 spores $/ 100 \mathrm{~g}$ soil with $\left(\mathrm{M}_{1}\right)$ followed by 288 , 276 and $269 \%$ expressed on $M_{5}, M_{4}$ and $M_{6}$, respectively compared with control 19 spores/ $100 \mathrm{~g}$ soil in the same ${ }^{15} \mathrm{~N}$-fertilizer dose. 
Results presented in Table 7 also show that AMF spore density in the rhizosphere of anise was determined at the end of the experiment increased significantly by AMF and/or microbial inoculation in all inoculated treatments. Mycorrhizal spore density in the absence of nitrogen fertilizer dose $\left({ }^{15} \mathrm{~N}_{0}\right)$ showed the highest level being 334 spores/100gsoil when inoculated with AMF individual $\left(\mathrm{M}_{1}\right)$ compared with un-inoculated control which was 22 spores/100gsoil in the same $\mathrm{N}$ dose. Also, with half recommended nitrogen dose $\left({ }^{15} \mathrm{~N}_{1}\right)$ the maximum level being 385 spores $/ 100 \mathrm{~g}$ soil in the treatments $\left(\mathrm{M}_{5}\right)$ compared with control (21 spores/100 g soil) in the same ${ }^{15} \mathrm{~N}$-fertilizer dose. In case of full recommended nitrogen dose $\left({ }^{15} \mathrm{~N}_{2}\right)$ the maximum was 337 spores $/ 100 \mathrm{~g}$ soil with $\left(\mathrm{M}_{5}\right)$ compared with the control (18 spores $/ 100 \mathrm{~g}$ soil) in the same ${ }^{15} \mathrm{~N}$-fertilizer dose.
Generally, The density of mycorrhizae spores significantly influenced by AMF and/or microbial inoculation. It is also clear from the results recorded that number of mycorrhiza spores in the rhizosphere soil of black cumin plant reached their maximal levels namely 377 spores $/ 100 \mathrm{~g}$ soil in treatment inoculated with mixed of AMF, Az.chroococcum and B.megatherium using half dose of nitrogen $\left({ }^{15} \mathrm{~N}_{1}\right)$ while the minimal one being 19 spores/100g soil in control with full recommended dose $\left({ }^{15} \mathrm{~N}_{2}\right)$. The number of mycorrhiza spores in the rhizosphere soil of anise plant reached their maximal levels which gave 385 spores $/ 100 \mathrm{~g}$ soil in treatment inoculated with AMF and B.megatherium $\left(\mathrm{M}_{5}\right)$ using half dose of nitrogen $\left({ }^{15} \mathrm{~N}_{1}\right)$ compared with the minimal one which being 18 spores/100 $\mathrm{g}$ soil in the control with full recommended dose $\left({ }^{15} \mathrm{~N}_{2}\right)$.

Table 7. Effect of inoculation with AMF and/or some beneficial microbes under labeled nitrogen $\left({ }^{15} \mathrm{~N}\right)$ fertilization on mycorrhizae spore density in the rhizosphere of black cumin and anise plants

\begin{tabular}{|c|c|c|c|c|c|c|}
\hline \multicolumn{7}{|c|}{ Mycorrhizae spore density spores/100g soil } \\
\hline \multirow{3}{*}{ Treatment } & \multicolumn{3}{|c|}{ Black cumin } & \multicolumn{3}{|c|}{ Anise } \\
\hline & \multicolumn{3}{|c|}{ Nitrogen $\left({ }^{15} \mathrm{~N}\right)$} & \multicolumn{3}{|c|}{ Nitrogen $\left({ }^{15} \mathrm{~N}\right)$} \\
\hline & $\mathbf{N}_{0}$ & $\mathbf{N}_{1}$ & $\mathbf{N}_{2}$ & $\mathbf{N}_{0}$ & $\mathbf{N}_{1}$ & $\mathbf{N}_{2}$ \\
\hline$\overline{\mathbf{M}_{0}}$ & 23 & 23 & 19 & 22 & 21 & 18 \\
\hline $\mathbf{M}_{1}$ & 344 & 344 & 305 & 334 & 326 & 296 \\
\hline $\mathbf{M}_{2}$ & 35 & 68 & 60 & 60 & 64 & 64 \\
\hline $\mathbf{M}_{3}$ & 33 & 78 & 65 & 69 & 67 & 79 \\
\hline $\mathbf{M}_{4}$ & 293 & 287 & 276 & 297 & 380 & 291 \\
\hline $\mathbf{M}_{5}$ & 279 & 334 & 288 & 328 & 385 & 337 \\
\hline $\mathbf{M}_{6}$ & 346 & 377 & 269 & 332 & 379 & 324 \\
\hline Mean & 193 & 216 & 183 & 206 & 232 & 201 \\
\hline LSD0.05 & M:27 & 17.89 & NM: 47.33 & M:12.32 & ; N: 8.062 & ; NM: 21.38 \\
\hline
\end{tabular}

Note: $\mathrm{N}_{0}, \mathrm{~N}_{1}$ and $\mathrm{N}_{2}$ are zero $\%, 50 \%$ and $100 \%$ Nitrogen $\left(\mathrm{N}^{15}\right)$, respectively from recommended dose.

$\mathrm{M}_{0}$ : control, $\mathrm{M}_{1}$ : AMF, $\mathrm{M}_{2}$ : Azotobacter chroococcum, $\mathrm{M}_{3}$ : Bacillus megatherium, $\mathrm{M}_{4}$ : $\mathrm{AMF}+$ Az.chroococcum, $\mathrm{M}_{5}: \mathrm{AMF}+$ B.megatherium and $\mathrm{M}_{6}: \mathrm{AMF}+$ Az.chroococcum + B.megatherium 
The obtained results revealed that no correlation can be drawn between number of Mycorrhiza spores in soil and inoculation with AMF and/or Az.chroococcum and B. megatherium according to Xavier and Germida (2003) since they observed some AMF spore associated bacteria (AMB) such as Bacillus pabuili have the ability to enhance AMF root colonization and can also improve plant growth (Artursson et al., 2006). Our results were in accordance with Pawaar and Kakde (2012) who found that the maximum spore population was observed during rainy season which coincides with flowering time of the plants. This may be correlated with the fact that during this period most photosynthatase is allocated to roots and rhizomes, which helps fungal symbiont to produce more spores (Wallen, 1980; Gemma and Koske, 1988).

\section{Note}

Data revealing the assessment of ${ }^{15} \mathrm{~N}$ and it's effect on the growth and productivity of the plants will be presented and discussed in our next work.

\section{REFERENCES}

Ali, F.S., G. Zayed, O.A. Saad and E. AbdulMohsen (2009). Optimization of nitrogen fertilizer level for maximum colonization of mycorrhizae on root of Coriander plants. Afri. Crop Sci. Soc., $9^{\text {th }}$ Conf., Cape Town, South Africa.

Alizadeh, O. (2012). A critical review on the nutrition role of arbuscular mycorrhizal fungi. Extreme life, Biospeol. and Astrobiol. Int. J. Bioflux Soc., 4 (1): 1-7.

Ardakani, M.R., D. Mazaheri, F. Majd and G.H. Nour-Mohamadi (2000). The study of Mycorrhiza and Streptomyces' efficiency and different levels of phosphorus on grain yield and some characters of wheat. Iranian J. Crop Sci., 2(2): 17- 28.

Artursson, V., R.D. Finlay and J.K. Jansson (2006). Interactions between arbuscular mycorrhizal fungi and bacteria and their potential for stimulating plant growth. Environ. Microbiol., 8: 1-10.
Biermann B. and R. Linderman (1981). Quantifying vesicular-arbuscular mycorrhizae: A proposed method towards standardization. New Phytol., 87: 63-67.

Cardoso, I.M. and T.W. Kuyper (2006). Mycorrhizal and tropical soil fertility. Agric., Ecosyst. and Environ., 116: 72-84.

Chandra, S. and H.K. Kehri (2006). Biotechnology of VA Mycorrhiza: Indian Scenario. New India Publishing Agency. Delhi, India, 23-70.

Chen, X., H. Wu Chun, J. Tang and S.J. Hu (2005). Arbuscular mycorrhizae enhance metal lead uptake and growth of host plants under a sand culture experiment. Chem., 60 (5): 665-671.

Constantino, M., R. Gomez-Alvarez, J. AlvarezSol' 1 s, V. Geissen, E. Huerta and E. Barba (2008). Effect of inoculation with rhizobacteria and arbuscular mycorrhizal fungi on growth and yield of capsicum chinense Jacquin. J. Agric. and Rural Develop. Tropics and Subtropics, 109 (2): 169-180.

Corkid, L., D.L. Rowland, N.C. Johnson and E.B. Allen (2002). Nitrogen fertilization alters the functioning of arbuscular mycorrhizas at two semiarid grasslands. Plant and Soil, 240 (2): 299-310.

Estefen, G., R. Sommer and J. Ryan (2013). Methods of soil, plant and water analysis: a manual for West Asia and North Africa region, Int. Cent. Agric. Res. Dry Areas (ICARDA), $3^{\text {rd }} \mathrm{Ed}$.

Fitter, A. and J. Garbaye (1994). Interactions between mycorrhizal fungi and other soil organisms. Plant and Soil, 159:123-132.

Frank, A.B. (1885). Uber di auf werzel symbiose beruhende Ernahrung gewisser Baume durch unterirdische plize. Ber. Dtsch. Bot. Ges., 3: 128-145.

Gemma, J. and R. Koske (1988). Seasonal variation in spore abundance and dormancy of Gigaspora gigantea and in mycorrhizal inoculum potential of dune soil. Mycologia, 80: $211-216$ 
Gerdemann J. and T. Nicolson (1963). Spores of mycorrhizalendogone species extracted from soil by wet -sieving and decanting. Trans. Brit. Mycol. Soc., 235-244.

Gerdemann, J. and J. Trappe (1974). The endogonaceae in the Pacific Northwest. Myc. Memoir., 5 : 1-76

Gianinazzi-Pearson, T. (1982). Relation between the critical concentration of nitrogen, phosphorus, and potassium in 17 different vegetable crops and duration of growth. J. Sci. Food Agric., 31:1343-1353.

Giovannetti, M. and L. Avio (2002). Biotechnology of arbuscular mycorrhizas. In: Khachatourians, G.G., Arora Dilip, K. (eds) Appl. Mycol. Biotechnol., Agric. Food Prod. Elsevier, Amsterdam, 2: 275-310

Hayman, D.S. (1982). Practical aspects of vesicular arbuscular mycorrhiza. In: Advances in Agric. Microbiol., (Subba Rao, NS Ed.). New Delhi, Oxford IBA, 325-373.

Heijden, V.D., J.N. Klironomos, M. Ursic, P. Moutoglis and R. Streitwolf-Engel (1998). Mycorrhizal fungal diversity determines plant biodiversity, ecosystem variability and productivity. Nat., 396:69-72.

Kapoor, R., B. Giri and K.G. Mukerji (2002). Mycorrhization of coriander (Coriandrum sativum $\mathrm{L}$.) to enhance the concentration and quality of essential oil. J. Sci. Food Agric., 82: 339-342.

Karagiannidis, N., T. Thomidis, D. Lazari, E. Panou-Filotheou and C. Karagiannidou (2011). Effect of three Greek arbuscular mycorrhizal fungi in improving the growth nutrient concentration, and production of essential oils of oregano and mint plants. Sci. Hort., 129:329-334.

Koul, K.K., S. Agarwal and L. Rafiq (2012). Diversity of arbuscular mycorrhizal fungi associated with the medicinal plants from gwalior-chambal region of madhya PradeshIndia. Ame.-Euras. J. Agric. Environ. Sci., 12 (8): 1004-1011.

Lestingi, A., D.D. Giorgio, F. Montemurro, G. Convertini and V. Laudadio (2007). Effects of bio-activators on yield and quality composition of triticale forage and food resource. J. Food Agric. Environ., 5 (1): 164171.

Mehrota, V.S. (2005). Mycorrhizas: Roles and Applications. Allied Publishers, New Delhi.

Mehrvarz, S., M.R. Chaichi and H.A. Alikhani (2008). Effects of phosphate solubilization of microorganisms and phosphorus chemical fertilizer on yield and yield components of barley (Hordeum vulgare L.). Ame.- Euras. J. Agric. Environ. Sci., 3(6): 822 - 828.

Mosse, B. (1981). Research Bulletin, Hawaii Institute of Tropical Agric. and Human Res., 194: 5-81.

Muthuraj, K., V.J.P. Joseph and N. Nagarajan (2014). Arbuscular mycorrhizal fungal diversity and root colonization of some medicinal plants rhizospheric soil of Madayipara Hills, Kannur, Western Ghat Kerala, World J. Pharm. and Pharmaceut. Sci., 3 (6): 1114-1122.

Pawaar J.S. and U.B. Kakde (2012). Study of arbuscular mycorrhiza associated with some important medicinal plants in Suburban Area of Mumbai. Online Int. Interdisciplinary Res. J., \{Bi-Monthly\}, II: 116-127.

Phillips, J. and D. Hayman (1970). Improved procedures for clearing roots and staining parasitic and vesicular-Arbuscular Mycorrhizal fungus for rapid assessment of infection. Trans. Br. Mycol. Soc., 55: 158161.

Ram, U. and S. Bhadauria (2009). Vesicular arbuscular mycorrhizal association with some medicinal plants growing on alkaline soils of Manipuri District, Uttar Pradesh, Mycorrhiza News, 13: 12-14.

Sarwade P.P., S.S. Chandanshive, M.B. Kanade and U.N. Bhale (2011). Diversity of Arbuscular Mycorrhizal (AM) Fungi in some common plants of Marathwada region. Int. Multidiscipl. Res. J., 1(12): 11-12.

Smith, S.E., and Read, D.J. (1997). Mycorrhizal Symbiosis. San Diego, California: Elsevier Science Ltd.

Smith, S.E. and D.J. Read (2008). Mycorrhizal Symbiosis. $3^{\text {rd }}$ Ed. New York, Acad. Press.

Soleimanzadeh, H. (2010). Effect of VA Mycorrhiza on growth and yield of Sunflower (Helianthus annus L.) at different 
phosphorus levels. Int. J. Chem. Biol. Engin., 3 (3): 159-163.

Trappe, J. (1982). Synoptic key to the genera and species of Zygomyceteous mycorrhizal fungi. Phyto. Pathol., 72: 1102-1108.

Urcoviche, R., M. Castelli, R. Gimenes and O. Alberton (2014). Spore density and diversity of arbuscular mycorrhizal fungi in medicinal and seasoning plant. Afr. J. Agric. Res., 9: $1244-1251$.
Wallen, B. (1980). Changes in structure and function of Ammophila during primary succession. Oikes, 34: 227 -238

Warner, A. and B. Mosse (1980). Independent spread of Vesicular Arbuscular Mycorrhizal fungi in soil, Trans. British Mycol. Soc., 74: $407-410$.

Xavier, L.J. and J.J. Germida (2003). Bacteria associated with Glomus clarum spores influence mycorrhizal activity. Soil Biol. Biochem., 35: 471-478.

\title{
تأثير التلقيح بفطريات الميكورهيزا الداخلية والنيتروجين المرقم على استعمار الجذور وكثافة الجراثيم في بعض النباتات الطبية
}

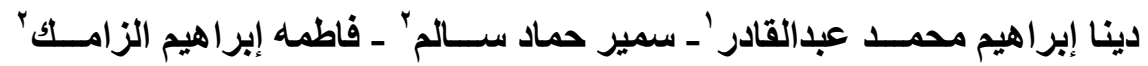

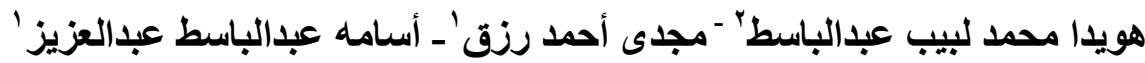

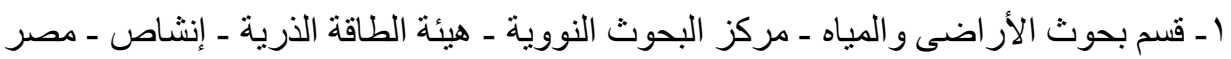

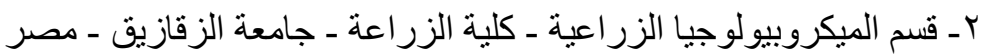

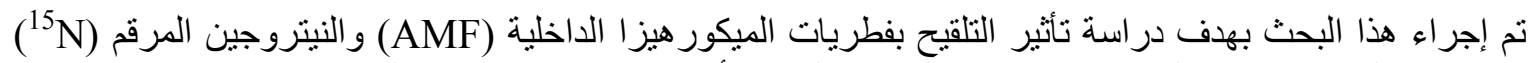

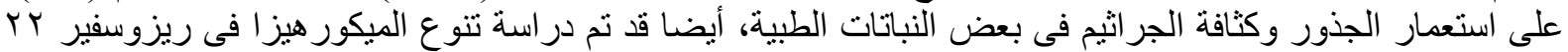

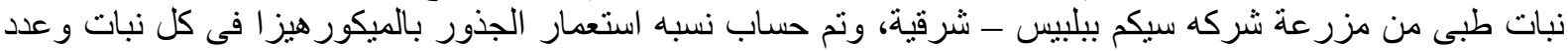

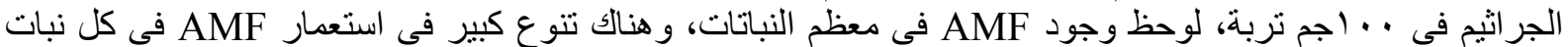

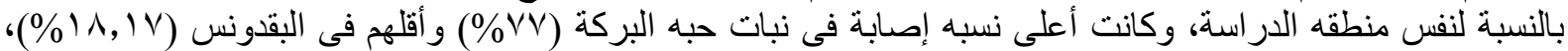

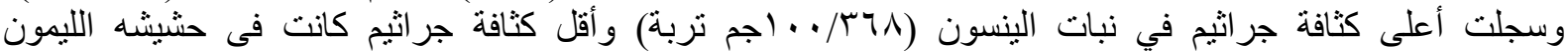

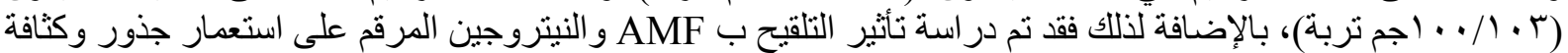

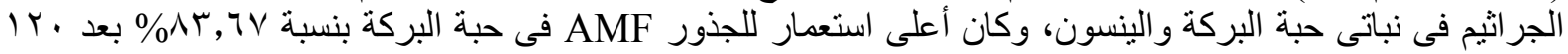

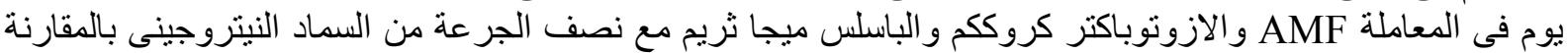
بأعلى استعمار للجذور

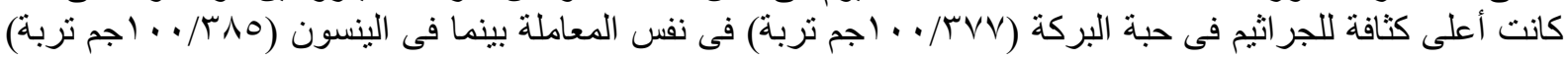
فى المعاملة AMF و الباسلس ميجا ثريم ونصف جر عة النيتروجين.
\end{abstract}

أستاذ الميكروبيولوجيا - كلية الزر اعة - جامعة عين شمس.

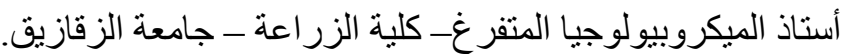

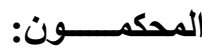

1 أ. أ.د. أحمد عبدالو هاب عبدالحافظ

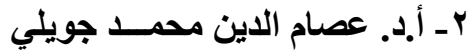

